\title{
ELECTIONS AND CONFLICT IN AFRICA: AN INTRODUCTION ${ }^{1}$
}

\author{
David K. Leonard \\ David K Leonard is Professorial Fellow in Governance, Institute of \\ Development Studies (UK) \\ e-mail: D.Leonard@ids.ac.uk
}

Since 1990 contested elections have again become a regular fixture of the political systems of sub-Saharan Africa. But what do they mean? In this issue of the Journal of African Elections we consider four important sets of African elections and the lessons that can be drawn from them, both for democracy and for best electoral practice. None of these elections was 'typical' for the continent. All were fiercely contested. Those in the Democratic Republic of Congo and Sierra Leone came after extended periods of civil war; Kenya's provoked a major outbreak of violence after the results were announced; while Nigeria's saw opposition wins at the sub-national level and loss of life around the polling itself. Each has something important to say about the meaning of elections in Africa and the challenges that arise in running them well.

\section{DEMOCRACY VS ELECTIONS}

What does democracy mean and why should it matter? From 1960 to 1990 Africa's 'one-party democrats' generally held sway, with the argument that democracy meant only the regular conduct of elections and perhaps the existence of primaries for legislative candidates of the ruling party. National unity was too precious and the dangers of ethnic violence were held to be too great for genuine contests for the presidency to be risked. Elections in this era should, most accurately, be considered to be plebiscites on the government of the day.

Only since the end of the Cold War has democracy in Africa come to mean the right to vote for the holder of executive power in multiparty elections. But even this change does not necessarily connote democracy, for such elections could be rigged or voters' choices significantly constrained. The most rigorous standards of democratic practice hold that citizens should be informed, uncoerced, and

1 The fieldwork for the studies included in this issue of the Journal was conducted between August and November 2008 and was financed by the UK Department for International Development (DFID) as part of a separate study on electoral assistance. The Swiss Agency for Development and Cooperation (SDC) contributed to the printing. The views expressed are those of the authors only and do not necessarily represent those of DFID, the UK government or SDC. 
effective in casting their votes - which implies the absence of election violence, parties that offer meaningful choices, well-functioning and independent media, rule through law, autonomous courts, and protection for the rights of minorities (and losers). In the articles in this issue we consider not only elections themselves but democracy (and its absence) in this larger sense.

A consistent lesson that emerges from these and other studies is that election support (be it international or domestic) is too narrow to achieve even good electoral outcomes. At a minimum, support for the electoral cycle is required and ideally the focus would be more broadly still on capacity building for the institutions that underpin democratisation.

\section{AN INSTITUTIONAL APPROACH}

Democracy is built by and results from the interaction of a significant number of the institutionalised behaviours and organisations present in a society. Some have direct roles, others indirect ones. Some are formal and openly acknowledged, others are informal and implicit. In these articles we highlight the array of institutions that have an impact on the elections, democracy and governance of our four selected countries.

\section{A context of patronage}

The first of these defining institutions is not an organisation, it is a behaviour. Political clientage is important in all of the political systems discussed in the following articles - even though it takes on distinctive features in each. Throughout Africa (and, indeed, in many other developing countries) voting is largely determined by ethnicity, kinship and neighbourhood. In rural areas, where all three tend to coincide, the result is that voting at polling-station level will generally be in favour of one particular candidate, with the decision effectively a collective one, sometimes enforced by implicit coercion. For example, Barkan, Densham \& Rushton (2006, p 933) found in Kenya that the average vote for the winning candidate for Parliament in 1997 was 65 per cent, even though there was an average of 4,4 candidates. At polling-station level this pattern of local consensus would be even more obvious. Only in the major urban areas is the coincidence of family and neighbourhood broken. Although kinship and rural ties will still be influential for all but second-generation urban elites, adherence to them will not be obvious in city polling stations.

This ascriptive voting behaviour is neither atavistic nor irrational. African states provide no reliable, formal systems of social security and individuals can rely only on their kin and neighbours for assistance. This not only strengthens the 
ties of ascriptive solidarity but also makes it rational for one to want state benefits to reach members of one's social group, even if one does not get them oneself - for those who receive them might be in a position to help in the future.

Not only does the above social dynamic lead voters to seek out patronage goods for their communities it also makes it relatively easy for political candidates to see whether the community around a particular polling station has been faithful to its part of the clientage bargain and has delivered - en masse - the expected votes. Visibility, and hence enforceability, make patron-client relations efficient and even more attractive (Kitshelt \& Wilkenson 2007). Thus, even if achievementoriented, policy-based political competition might produce better results for the country as a whole the individual politician, community and voter will find patron-client political ties rational. Given this analysis, the emphasis international NGOs put on the moral superiority of issue- or policy-based voting in the election education they finance in Africa seems slightly naïve and not wholly resonant with the benefits rural citizens are actually likely to be able to derive from their votes.

Politicians who fail to provide jobs, infrastructure and other elements of patronage will disappoint their electorate and be vulnerable to challenge in the next election - either from the opposition (most often in an urban area) or from another faction of the party (in most of the countryside). The temptation to be corrupt and profligate with the public purse in order to gain patronage for personally targeted distribution (with some personal wealth on the side) is overwhelming.

Of course an elected office holder could (and should) provide constituency service without being corrupt. Constituency service is a benefit provided to all individuals of a certain place or category, regardless of their personal votes. Patronage, on the other hand, is visibly targeted only to those who are supporting the politician, so that the benefit is a reward for political backing. ${ }^{2}$ The boundaries between constituency service and patronage overlap, but the end points of the continuum they describe are clearly different.

Patronage is politically more efficient than constituency service and is much more prone to corruption. But this poses a dilemma for the politician if the state is overwhelmingly dependent on donor aid projects and budget assistance which could be cut off if the international community detects persistent significant corruption (as it is in the DRC and Sierra Leone). In Sierra Leone, for instance, donor sanctions for corruption led to a reduction in the funds for generating constituent benefits. It is central to a politician's re-election that visible benefits

2 The fact that patronage works best when it is a 'private good' or a community one and the damage this does to the larger 'public goods' component of most valuable public policy is well analysed in Bates (1981). 
are delivered to his / her constituents. The challenge for politicians in Sierra Leone is to learn how to do this within the boundaries of donor-defined probity - which requires that they move along the patronage-constituency service continuum towards the non-corrupt and collective end. This is appropriate, but it is not easy in these societies and is facilitated by development assistance that generates the kinds of benefits that are visible and demanded by the critical parts of the electorate.

\section{Strong presidents}

African states are weak in the face of very strong societies (Migdal 1988). As Aristide Zolberg noted 40 years ago, this makes nervous national politicians construct governmental systems that are as strong as possible - hence the long period of one-party rule on the continent and the persistence even today of very strong presidencies (Zolberg 1966).

The resulting problem is that the stakes for winning or losing State House become inordinately high. A key dimension of the violence that frequently surrounds presidential elections in Africa is the extreme concentration of authority in the presidency, with almost no checks on its power. Deconcentration of the presidency's powers can follow from a number of coordinate reforms - the creation of a prime minister with specified authority, an enhanced role for Parliament, an independent and impartial judiciary, legal limits on what civil servants can be asked to do, and devolution of authority to local-government bodies. The Democratic Republic of Congo and Kenya are prominent examples of systems that now pair a directly elected president with a prime minister elected by Parliament. In Kenya, presidential resistance to a prime ministership was one of the factors that contributed to the election violence that occurred in 2007 / 08 before the change was adopted in the peace settlement.

\section{Parliaments of rural ambassadors}

When patron-clientage is combined with a strong presidency the legislature becomes a collection of (largely rural) ambassadors petitioning for patronage goods they can distribute to their constituencies (or turn into personal wealth for themselves, which, in turn, can be used to make them generous 'big men' at home). For members of Parliament who operate in these circumstances deliberating on public policy, passing laws, and holding government accountable are minor activities when seen from the point of view of re-election. To some extent the same can be said of first-past-the-post (FPTP) constituency legislators everywhere. But the strength of society and the presidency in Africa makes the tendency much stronger. 
It is difficult in most of Africa to produce competitive political parties based on public policy differences rather than the distribution of patronage - at least until the issues around service provision shift from their physical presence in particular constituencies to their general quality and until income from oil-rich or aid dependent states is no longer the most important source of income for the elite. An empirical example of this, from Nigeria, is the failure to take hold of the Social Democratic Party (SDP), which the late Prof Claude Ake worked so hard to base on policy positions. Similar attempts have failed in Kenya and elsewhere in most of sub-Saharan Africa.

Despite the fact that MPs receive few electoral rewards for paying attention to legislation, executive accountability and the public interest more generally, in all four of the countries examined in this issue a few MPs (perhaps because of something in their personal or professional background) did care about these matters and often enabled these parliaments to be more effective than the general political culture would give one a right to expect.

\section{The electoral system: what is one trying to achieve?}

In a democracy, of course, the electorate selects the executive and legislature. The behaviour and choices of the voters (as well as those competing for their favour) are shaped by the nature of the electoral system. We have a rich literature and body of empirical knowledge in political science about the impact of various electoral systems, dating, at least, from Maurice Duverger (1950). There has been a temptation to interpret this understanding in such a way as to prescribe a 'one best way' for choosing representatives democratically. These four case studies, however, demonstrate that various countries may be faced with quite dissimilar challenges and therefore need different electoral and representational systems to deal with them. Once we ask how to maximise a given value we have a body of knowledge from which we can draw a reliable answer. But we are often not giving proper attention to the fact that the questions to be asked and the values to be optimised vary according to the condition in which a country finds itself.

Our case studies provide multiple illustrations of this principle of variation. When Africa first became independent it was feared that the state would not be strong enough to resist the divisive forces of multiple, competing ethnicities. Thus prime ministers responsible to parliaments were abandoned in favour of presidents directly elected in single-party systems. Now that most of Africa has been independent for nearly half a century it is evident that secessionist movements have proved a much smaller threat than anticipated and that the real threat is the monopoly of political power of strong presidencies. Thus, prime ministers who share executive power with presidents are back in vogue. They deconcentrate 
power, broaden the number of ethnic groups that can control executive authority, and strengthen parliaments by making MPs the final electors of this particular office. The problem shifted and thus so did the answer. Another type of problem concerns the ways in which elections can mitigate or exacerbate violence. In Kenya the president must not only win a plurality of the vote but at least 25 per cent of the vote in five of the country's eight provinces. These requirements mean that there can be a large premium attached to minority votes in some areas.

In three separate general elections the Kalenjin in the central Rift Valley have mobilised to attack the Kikuyu settlers living there. The Kikuyu are a minority in the Rift Valley but are the largest group in the country as a whole; their presidential candidate can be denied office by making it impossible for his supporters to win the constitutionally mandated provincial minima. If the executive is selected instead by members of Parliament elected in FPTP contests (as Kenya's prime minister now is) the motive for attacking minority voters is dramatically reduced. On the other hand, a national proportional representation (PR) system would make the likelihood of violence greater.

In the Democratic Republic of Congo the electoral system was designed to solve several urgent problems: (a) to get ethnically-based minority militias to turn from military to electoral combat; (b) to give remote local communities (which had become distanced from the state) a strong sense of being represented in the capital; (c) to find a way of distributing legislative positions proportionately when there had been no recent census; and (d) to overcome local fears that national political party elites would manipulate the system to impose unpopular MPs on local communities.

The first problem meant that an electoral system that permitted competition only among multi-region national parties would fail to bring the local militias into the civilian system. The second objective would best be met by singlemember (SM) constituency FPTP elections. The third problem meant that it was hard to know before the election what the appropriate regional distribution of parliamentary seats would be, thus reliance only on SM-FPTP would be likely to be unrepresentative. The fourth and final fear meant that any PR would have to be done by open list $(\mathrm{OL})$ - where people vote for individual party members and the number of MPs a party gets is determined by the total number of votes its party nominees get and the rank order of the party's candidates on its list would be determined by the votes they personally received from the electorate.

A closed list (CL) PR would have exacerbated local fears of elite manipulation. The real problems and multiple constraints facing the DRC in this first post-conflict election meant that it opted for a combination of SM-FPTP and PR-OL MPs selected at district level. The resulting system was very complicated and may need to be revised in the future. But it did achieve its most critical objectives. 
The DRC illustrates in another way as well the proposition that there is no one best way. It is well known that if one wishes to increase the number of women in a legislature the best way to do this is through PR-CL, with the political parties legally required to field a certain percentage of women candidates at all levels of the list. Some international women's groups have criticised the DRC for failing to use this method in its election. The objective of these groups is legitimate and their analysis of the consequences of different electoral systems is correct. In the case of this post-conflict election, however, it seems to me that the average woman had a greater interest in the achievement of peace than she did in seeing an increase in the numbers of elite women MPs.

The point our cases make, then, is that context is hugely important and the best electoral system is one shaped to meet the key questions the context throws up rather than one that opts for a universal, 'best practice' template. A number of studies can be used in undertaking this more complex exercise (eg, Jones 1995; Lijphart 1994; Reynolds 2002; Reynolds, Reilly \& Ellis 2005; Taagepera \& Shugart 1989).

\section{Election management bodies}

The competent and impartial conduct of an election is fundamental to its success, of course. Elections are immensely challenging logistically and none of the countries we studied handled them perfectly. But they also create great incentives to cheat and there is substantial political pressure on the electoral management body (EMB) to tilt in favour of those in power. International assistance and unusual integrity on the part of the EMG chairs were critical to the satisfactory performance in the DRC and Sierra Leone. In Kenya an EMB chair of past integrity resisted international assistance, and cheating at the polls overwhelmed the system. In Nigeria the EMB has been widely condemned for complicity in the dishonesty and logistical failures that were evident on election day.

But EMBs do not act alone. Civil society organisations (CSOs) and nongovernmental organisations (NGOs) that carry out voter education and monitor the polls on election day are also critical. And these, in turn, have come to be dependent on financial support from donor nations and the moral support of international election observation teams. In Africa the latter are not only accepted (despite their apparent affront to sovereignty) but are sought out (for the added international legitimacy they can confer). This fact both provides leverage and creates a danger. There can be times when external interests (such as dependence on Nigeria's oil) can make a country want to pull its punches on what its observers have seen on election day. Perhaps this is inevitable in some circumstances in a world of real politic but it is better for potential international observers to refuse 
to participate at all than to be complicit in a report that tells less than the full truth or is overly subtle in stating it. As was evident in Nigeria, locals who have risked their lives trying to deliver democracy can feel deeply betrayed when the internationals who seemed to be encouraging them back away from being frank themselves.

\section{Courts}

Competent and independent judiciaries are also central to democracy. If court decisions are not rendered in a timely and intelligent manner or if judges see themselves largely as instruments of the executive, the laws produced by parliaments can have no effect and citizens have no protection. Such courts are also central to the resolution of the disputes elections inevitably create.

In the cases examined in this issue courts tended to render electoral decisions based on narrow technical criteria rather than substantive justice, to be so slow as to render their deliberations irrelevant, or to see themselves as instruments of the interests of the incumbent executive. A few exceptional, courageous decisions have been handed down, particularly in Nigeria, but they are rare. The absence of a genuinely independent and timely judicial process was a significant factor contributing to post-election violence in the disputed Kenyan elections. The all-too-prevalent neglect of this key institution of democracy served to weaken elections in these countries.

\section{Security services}

Elections are a valuable means of managing societal conflicts - potentially providing less violent fields for contesting differences, creating the possibility of political change without rending the fabric of society, and instituting some modest degree of accountability of the government to its citizens. But if elections are not conducted properly they can crystallise and accentuate the very conflicts they should be helping to manage. Elections as alternatives to violence in the resolution and management of societal conflicts can be realised only if they are overseen by impartial dispute resolution bodies (electoral management body and courts) and security services (police and army). Otherwise the temptation to cheat and use coercion to achieve the desired outcome escalates and may, itself, precipitate violence.

In the DRC and Sierra Leone international players were central to the achievement of security services that deterred electoral violence. In Kenya the army insisted on remaining neutral because of the experience it had gained in international peace keeping missions. But in Nigeria and Kenya police 
performance was deficient - perhaps because they were more isolated from international involvement and therefore more vulnerable to politication.

\section{MULTI-LEVEL, NETWORKED GOVERNANCE}

International players did not merely facilitate the electoral processes in the DRC and Sierra Leone they played a central role in assuring that the elections went well. Was such a role legitimate? By the traditional standards with which we evaluate sovereignty the answer would be 'no, states should determine their own governance procedures'.

This purist stance is, however, flawed and unrealistic. First, during their civil wars both countries had ceased to be states in any empirical sense (and thus entitled to sovereignty). Without external involvement the two states would not have been reconstituted and there would have been no elections to hold. Secondly, contemporary globalisation is not just an economic phenomenon, it is also a political one. Though the World Bank and the UN are 'apolitical' and proclaim their respect for sovereignty they are deeply involved in promoting governance reforms, and bilateral donors both lead and follow in this endeavour.

Whether one likes it or not the reality is that governance in all countries is determined by the complex interactions and networks of myriad actors at multiple levels - from chiefs in the villages to army colonels, to presidents, to bilateral donors, to international organisations. Perhaps the formal, national government is weaker in these interactions in Africa than it often is elsewhere, but this is a difference in degree not in kind. Today it seems far more appropriate to evaluate the effectiveness and democratic integrity of these multiple forms of influence and the networks they create rather than to challenge their existence in the name of sovereignty (Ansell 2000; Ansell \& Gingrich 2003).

Thus, in our analysis of these African elections both local and international players receive prominent attention. Who was willing or able to do what, with what kind of networks emerges as central to electoral success and ultimately to democracy.

\section{WHO BENEFITS?}

\section{A development perspective}

In development theory democracy is important because it adds to the ability of people to make meaningful and informed decisions about their own lives, just as do improvements in security, health, income and education (Sen 1999; Uphoff \& Ilchman 1972). 
Democratic theorists tend to value the direct control over the political aspects of their destinies that elections and human rights protections give to citizens. But development specialists are often interested at least as much in the indirect benefits for people's lives that democracy might provide in the form of stability, economic development, or public services. Thus it is worth asking just what, in practice, in any given country, democracy is actually delivering and to whom? If democracy doesn't improve the aggregate choices people have in their lives as much as alternative systems of governance are believed to do citizens might choose not to have it (as seems to be happening in Russia today). And who, in specific practice, is benefiting from it - the poor, the elite, or possibly even the donors who need to make a show of it to satisfy their own electorates?

\section{The poor}

The main benefit the poor of Africa derive from 'free and fair' elections is the patronage that is directed to them in the competition for their vote. When the competition diminishes or the results are rigged the flow of patronage goods to the bottom of the system is reduced.

This is most obvious in a comparison between Kenya and Nigeria. In the latter patronage has turned into prebendalism, an intra-elite form where elections are 'delivered', not won, and the benefits of office do not get far beyond the holder. In the former, where competition for Parliament is intense, candidates spend substantial sums on direct benefits for voters and their communities.

Even where there is considerable electoral competition patronage will not deliver national economic policies that are particularly pro-poor (for patronage provides private goods at the expense of public ones) nor will it mean that government is accountable to its citizens or their representatives. But in systems in which basic rural services (such as health, education and roads) are not being supplied at even minimal standards, where rural communities are the sole locus of social welfare, and where jobs for unskilled labour are woefully short, patronage is providing considerable benefits. The side effects of corruption and elite oriented national economic policies are often deeply disappointing. But when we compare patronage-ridden competitive democracies with most of their authoritarian counterparts we do, frequently, see some benefit. Authoritarian systems can be more progressive than democracies, but it seems unwise to count on their existence or their continued performance.

\section{The elite}

Even when elections are not 'free and fair' they may be important to civilian elite bargains. This is most evident in Nigeria, where the important election results 
are determined before anyone goes to the polls. Despite widespread lack of confidence in the electoral process Nigerians have demonstrated support for the idea of elections, not only as the alternative to the military in the selection and recruitment of the political leadership but also as the marker for the authority that is being granted to an office holder and the term limits on holding it. These features have been evident in Kenya as well, even in its undemocratic phase.

\section{Peace}

Elections can be instruments for both the exacerbation and the management of conflicts. If they are poorly managed, as they were in Kenya and Nigeria, they can become stimuli to violence. This makes it all the more important that they be conducted competently and with integrity.

In a number of circumstances, however, well-managed elections have advanced the cause of domestic peace after prolonged periods of civil war (Elbadawi \& Sambanis 2000). This was the case in both the DRC and Sierra Leone. This is not to say that progress toward peace was automatic, much less complete; there are many steps still to be taken and many dangers remain after the elections. Critical prerequisites for these modest successes have been international players who were willing to guarantee the relative integrity of the electoral processes (so that all parties to the conflict felt that they had a fair prospect of gain) and were willing to continue after the elections to ensure that the bargains struck in the run-up are honoured.

Genuinely credible commitments to enforcing the fairness and continuity of the constitutional arrangements established in peace negotiations are fundamental to their long-term success (Lake \& Rothchild 2001; Leonard \& Straus 2003, chap 5). It is precisely for this reason that democracy can succeed only if powerful players are committed, not just to election cycles rather than elections, but to continued cycles until the commitments made in the peace settlement are well institutionalised.

\section{The international community}

Finally, elections help donor agencies legitimise their operations with their head offices and electorates at home. This is not just a self-serving benefit, it enables donor agencies to justify expenditure on development assistance for states that are more democratic and encourages Organisation for Economic Co-operation and Development foreign ministries to exercise diplomacy on behalf of these client states, an element that has been significant for the DRC. Once its elections had been completed satisfactorily major powers felt able to put pressure on Rwanda 
to negotiate a set of measures that would remove the threat to Congo's peace posed by Rwandan militias in the eastern DRC.

\section{- REFERENCES -}

Ansell, C. 2000. 'The Networked Polity: Regional Development in Western Europe'. Governance 133, pp 303-333.

\& J Gingrich. 2003. 'Trends in Decentralization'. In B E Cain, R J Dalton \& S E Scarrow (eds). Democracy Transformed? Expanding Political Opportunities in Advanced Industrial Democracies. Oxford: Oxford University Press.

Barkan, J D, P J Densham \& G Rushton. 2006. 'Space Matters: Designing Better Electoral Systems for Emerging Democracies'. American Journal of Political Science 50(4), October.

Bates, R. 1981. Markets and States in Tropical Africa. Berkeley: University of California Press.

Duverger, M. 1950. L'influence des systèmes électoraux sur la vie politique. Paris: A. Colin.

Elbadawi, I \& N Sambanis. 2000. 'Why Are There So Many Civil Wars in Africa? Understanding and Preventing Violent Conflict'. Journal of African Economies 93.

Jones, M P. 1995. Electoral Laws and the Survival of Presidential Democracies. Notre Dame: University of Notre Dame Press.

Kitshelt, H \& S I Wilkenson. 2007. 'Citizen-politician linkages: an introduction'. In H Kitshelt \& S I Wilkenson (eds). Patrons, Clients and Policies: Patterns of Democratic Accountability and Political Competition. Cambridge: Cambridge University Press.

Lake, D \& D Rothchild. 2001. 'Containing Fear: The Origins and Management of Ethnic Conflict'. In M E Brown, O R Cole, S M Lynn-Jones \& S E Miller (eds). Nationalism and Ethnic Conflict Revised Edition. Cambridge, MA: MIT Press.

Leonard, D K \& S Straus. 2003. Africa's Stalled Development: International Causes and Cures. Boulder, Colo: Lynne Rienner.

Lijphart, A. 1994. Electoral Systems and Party Systems. New York: Oxford University Press.

Migdal, J. 1988. Strong Societies and Weak States: State-Society Relations and State Capabilities in the Third World. Princeton: Princeton University Press.

Reynolds, A (ed). 2002. The Architecture of Democracy. Oxford: Oxford University Press. 
— , B Reilly \& A Ellis (eds). 2005. Electoral System Design: The New International IDEA Handbook. Stockholm: International Institute for Democracy and Electoral Assistance.

Sen, S A. 1999. 'Democracy as a Universal Value'. Journal of Democracy.

Taagepera, R \& M S Shugart. 1989. Seats \& Votes. New Haven: Yale University Press.

Uphoff, N T \& W F Ilchman. 1972. 'Development in the Perspective of Political Economy'. The Political Economy of Development. Berkeley: University of California Press.

Zolberg, A. 1966. Creating Political Order: The Party-States of West Africa. Chicago: Rand McNally. 